\title{
Men and Media: \\ Friends or Enemy of Women Parliamentarians? Under-Representation of Women in Politics
}

\author{
By Dorota Opyd
}

So now women think they are capable of holding the highest office in the land. It's bad enough that we allow these female creatures to operate automobiles. Imagine what would happen if one of them became president! Let's keep women at home where they belong

(Krasner, 1964: edited in Falk, 2008: 31)

Many years have passed since women obtained voting rights. Although role of women in political, economic and social life has largely increased, they are still relatively poorly represented at the top of managerial positions and rarely reach the areas of political authority. In the modern politics, women's low presences in parliaments around the world become a central issue among society (Ballington 2009). Recent developments in the field of gender equality have led to renewed interest in this domain and finally have been acknowledged for the first time in history as being problematic (Sawer, 2010). Recent evidence suggests that as the number of women's population varies around 50 per cent (UNSD, 2012), the importance of equal access to decision making for women cannot be ignored (Ballington and Karam, 2005; Haffert at el, 2010).

This paper investigates the barriers to gender inequality created by male domination and unequal representation of women politians by media in national politics and also explores the ways in which these difficulties are experienced. The study illuminates the position, perception and thoughts on women's political careers and explores the reasons for gender inequality in the political elite across some european parliaments.

\section{Introduction}

Past research offers a variety of examples and explanations on women under-representation in politics and expresses women's determination to join the political elite. Moreover, researchers and academics have identified numerous approaches undertaken by political parties and women themselves in order to join parliamentary life such as male domination of parliaments and unequal representation of women politicians by media. Hence, the aim of this paper is to explore, examine and summarize the findings from existing

*PhD Student, University of Liverpool, UK. 
literature on the impact of male and media on women's under-representation in national politics.

As a point of departure, an argument by Nelson and Chowdhury (1994:3) that in no country do women have political status, access, or influence equal to men', successfully reflects the significance of this topic. Furthermore, as a result of this under-representation men still dominate the political arena (IPU, 2012) and the image of parliamentarians definitely shows a man's face (Zukowski, 2011). To give an answer to my second enquiry on who prevents the exertion of women's desire to join the political elites the examples of media representation of women political leaders have to be discussed in this paper as media can make or break their reputations (Marszalek-Kawa, 2010, Zukowski, 2011; Ross and Comrie, 2012). Many researchers illustrate that the balance of media friendliness in the image of women politicians versus men politicians has been significantly unequal, presenting women in a distorted manner (Marszalek-Kawa, 2010, Zukowski, 2011).

\section{Outline of the Problem of Gender Parliamentary Imparity}

'There are very few jobs that actually require a penis or vagina. All other jobs should be open to everybody'

(Florynce Kennedy ${ }^{1}$ (1916-2000) cited in Krolokke and Sorensen, 2006: 8)

Multiple sources in the current literature on women's political underrepresentation refer to a variety of women movements in highlighting wider path of this phenomenon. Women's fight for civil and political rights has its roots in 1848, when the first women's movement originated in the US (Krolokke and Sorensen, 2006). The importance of women's role in legislative bodies has been acknowledged since the beginning of the 20th century (Lovenduski and Karam, 2002; King, 2005). From the 1970s, women's marginal presence in parliaments around the world emerged as an important social and political issue (Inglehart and Norris, 2003; Wawrowski, 2007; Ballington 2009). Furthermore, a range of global public surveys carried out between 1995 and 2005 suggested that public awareness of gender inequality in the political sphere has risen significantly (Fushara cited in MarszalekKawa, 2010).

As statistical data suggests, the proportion of women in the population always varies around 50 per cent (BIS, 2011; Ruedin, 2010; Krook, 2010; Mediocre, 2011; UNSD, 2012), therefore the importance of equal access to decision making for women cannot be ignored (Ballington and Karam, 2005; Haffert at el., 2010). I will therefore start my discussion with Abdela's (2010:18) argument that 'democracy is not democracy when over half of the population is not fully represented' and 'the achievement of democracy presupposes a genuine partnership between men and women in the conduct of

${ }^{1}$ Florynce Rae "Flo" Kennedy (February 11, 1916 - December 22, 2000), was an American lawyer, activist, civil rights advocate, and feminist. 
the affairs of society' (IPU, 1997:2). Furthermore, many scholars claim that equal gender representation is a necessity for a democratic society (Norris, 1996; Dahlerup and Freidenvall, 2008; Kampichler and Machovcova, 2008; Abdela, 2010; Pawlowski and Kierulf-Dubrow, 2011).

Past research offers significant data on women's parliamentary involvement and statistical data regarding this issue has been established by researchers who have conducted various national and international studies. According to Stockemer (2007), in 1950 women's parliamentary representation across 27 European Union Countries was on average 5.4 per cent and this continued until the 1960s. The only differences could be noticed in Nordic countries, where women's representation in the 1950s was higher than 10 per cent, establishing its roots as the highest over the last 30 years (Dahlerup and Freidenvall, 2008). However, further statistical evidence reveals that after the 1960s there was a slight increase in women's representation globally (Ballington and Karam, 2005). Ruedin's (2010) analysis of the InterParliamentary Union's (2006a) data found that in countries with smaller populations and parliaments, women's representation was lower. This could be due to a limited number of seats available in small chambers, where a single seat can be as much as 7 per cent of all seats (IPU, 2006a; Ruedin, 2010). Also, a very important factor is associated by different influences such as social and political changes, increases in economic growth (Walby, 2004) and party quotas (IPU, 2006a; IPU, 2006b). Currently women's representation in worldwide parliaments represent around 20 per cent (Stockemer, 2007; IPU, 2011) as presented in Figure 1.

Figure 1. Average of Women in Parliaments Worldwide in 2011

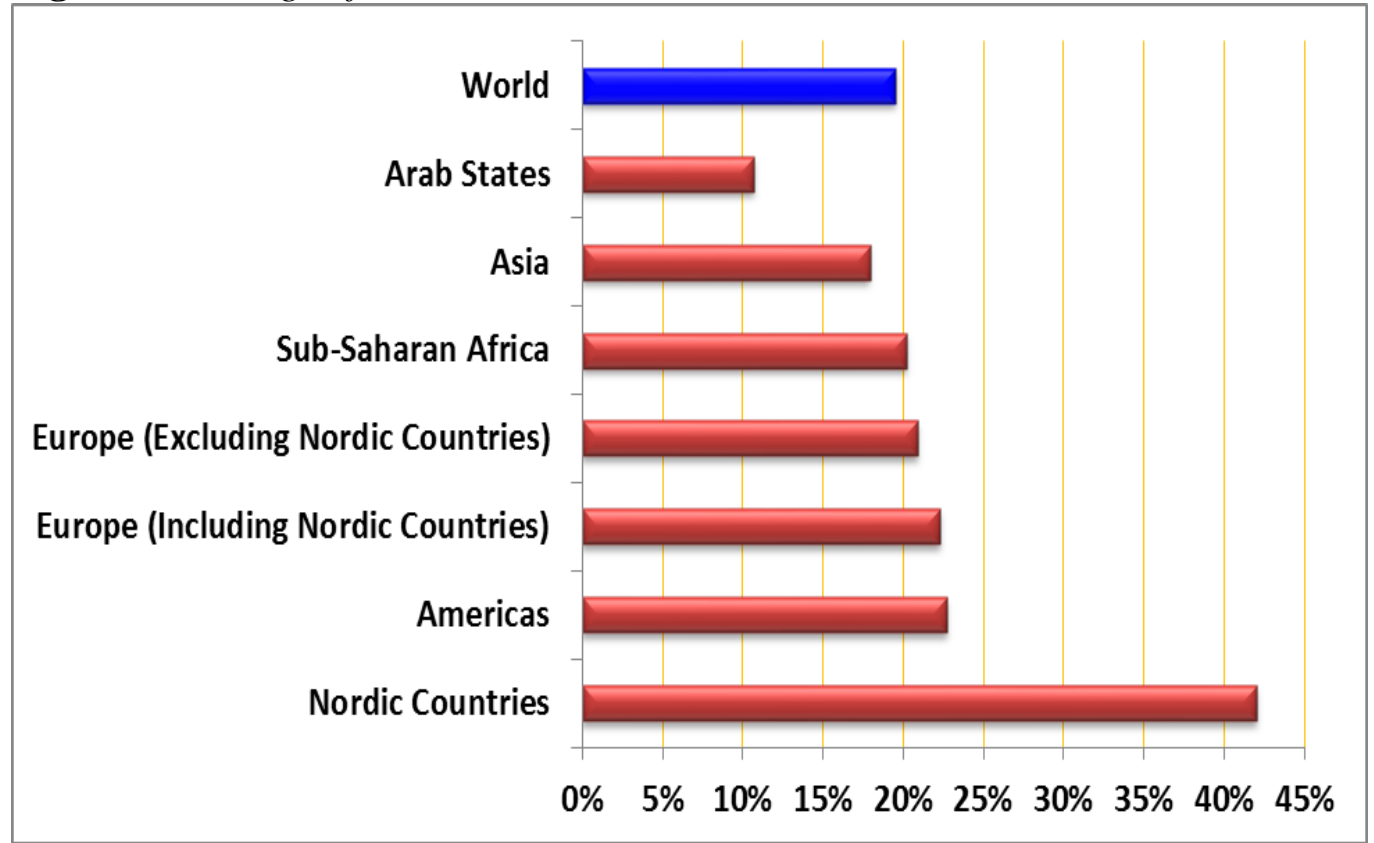




\section{Male Domination of the Political Arena}

'In a society where some groups are privileged while others are oppressed, insisting that as citizens persons should leave behind their particular affiliations and experiences to adopt a general point of view serves only to reinforce that privilege; for the perspectives and interests of the privileged will tend to dominate that unified public, marginalizing or silencing those of other groups' (Young, 1989:257 cited in Ross, 2002:13)

The risk of women's inability to cope with the male-dominated 'heat of the parliamentary kitchen ', appears to be a big concern in society (Childs et al., 2005: 69). Men's dominance of the political arena has been reflected on by many academics and is proven to be one of the major difficulties that discourage women from joining the political sphere (IPU, 1999; Unicef, 2007; Mediocre, 2011). For example, The Panhellenic Socialist Movement in Greece speaks of a 'lack of interest due to the hostile climate and strong competition from men' (IPU, 1999). Furthermore, Ballington and Karam (2005: 13) argue that public perceptions on gender roles suggest that the social contract is about the relationship between men and government and not citizen and government'. It is ironic that England was actually called by John Bright ${ }^{1}$ : 'the mother of parliaments', as Westminster has been largely occupied by males (BBC News, 1998; Childs, Campbell, Lovenduski cited in Tremblay, 2008:41). The discussion on local elections in one of the leading Polish newspapers, Rzeczpospolita, was titled: 'The Republic of Men' (Platek, 2004: 20). Furthermore, the British House of Common is very often described as an 'old boys club' (Childs et al., 2005:68), as a 'Gentleman's Club' (Harman and Mattinson, 2000:20), or as a 'boys' school which has decided to take a few girls' (Vallance, 1979: 6).

In addition, Even Coward (1999:212 cited in Walsh, 2001:19) distinguishes that one of the biggest problems for women being not recognized as successful leaders or not being able to hold power in a public domain is 'networking and men's narcissistic interest in each other'. One Polish woman MP from the SLD stated that women always lose with men who are obsessed with success and will do anything to get it, even if it takes 'walking over dead bodies' (Pankow and Post, 2010:22). Also, according to another Polish women MP (Samoobrona RP) 'even the stupidest man feels that he is cleverer than the cleverest woman' (Pankow and Post, 2009: 64). Therefore, in order to get into and survive the political competition women have to be better and try much harder than men (Warowski, 2007; Fuszara, 2009). Consequently, it is tougher for women in public life, as they have to be feminine and masculine at the same time (DuVall, 2009). Margaret Hodge (Labour MP, UK) admits that one of the aspects of male domination in the House is their physical ability to shout

\footnotetext{
${ }^{1}$ John Bright (16 November $1811 \quad$ - $27 \quad$ March 1889), Quaker, was a British Radical and Liberal statesman, associated with Richard Cobden in the formation of the Anti-Corn Law League. He was one of the greatest orators of his generation, and a strong critic of British foreign policy. He sat in the House of Commons from 1843 to 1889.
} 
over women as their voices are stronger (Hodge cited in Ross, 2002). According to several British women MPs, some sessions across the Labour Party were organized to help women MPs to practice asking questions in open forums by 'not just asking them, but shouting them' (Vallance, 1979: 15).

In order to build on the philosophy of men's resistance to women entering the parliamentary environment, I would indicate a critical mass phenomenon which according to some scholars may not only distort the political scene (Pankow and Post, 2009; Zukowski, 2011) but make its environment unstable for men (Zukowski, 2011). According to its theorists, critical mass is established when 30 per cent of gender representation (or 1/3) occupies the same institution or in some instances when a 60:40 ratio is achieved (Kanter, 1993 cited in Stevens, 2007; Squires, 2007; Zukowski, 2011; Sawer, 2012). Academics suggest that when women achieve the large minority identified as critical mass (Lovenduski, 2001; Chids and Krook, 2008; Wangnerud, 2009), the transformation in politics and its functioning will be considerable, not only for the institution (Kittilson, 2006; Pankow and Post, 2010; Zukowski, 2011) but also for public policy (Squires, 2007). Additionally, some scholars claim that critical mass could promote 'feminist-orientated change' on a larger scale (Ross, 2002; Siemienska, 1997; Stevens, 2007:179; Zukowski, 2011). However, the extension of the changes would still depend on how many women triumph and enter parliament (Lowenduski and Karam, 2002). Also, it is inevitable that women's dominance in parliament would change the behavior of men MPs (Lowenduski and Karam, 2002; Sroda, 2009). As an example, Norris (1996) illustrates that in some Scandinavian countries, the political structure has already become more feminine due to the critical mass phenomenon. This change also can be seen in the Polish Sejm where, out of 69 women MPs, 63 declared that their style of doing politics was different and more feminine (Pankow and Post, 2009).

An important issue in this debate is women's sexual harassment by men MPs. As an example, a Polish female MP's (SLD) statement can be used here. She expressed her view that it was always irritating when men paid more attention to how women look rather than their abilities. She felt that men MPs were treating their women colleagues more like 'an attraction of the building or a nice bouquet on their table' (Pankow and Post, 2009: 31). Also sexism is alive in the British House of Commons (Sones et al., 2005; Lovenduski, 2005 cited in Stevens, 2007). Some reports by Labour and Conservative women MPs cite remarks made by their male colleagues about 'legs and breasts' and male MPs making sexual gestures such as 'putting their hands out in front of them as if they are weighing melons' during speeches by women MPs (Childs, 2004, in Childs et al., 2005: 71). Another good example of sex discrimination is presented by Shepherd-Robinson and Lovenduski (2002: 121 cited in Childs et al., 2005: 23) where a woman candidate for the 2001 election was told by her male colleague: 'Well, you didn't do bad for a little woman, did you?' Similarly, another woman candidate for the same election was told: 'we do enjoy watching you speak; we always imagine what your knickers are like' (Lovenduski, 2005: 77). 


\section{Media: Friends or Enemy of Women Politicians?}

Previous research also identifies the media as key players in the lasting involvement of women in politics. Being a politician counters not only leadership and power but also exposure of a personal image. Many academics exemplify that the balance in presenting images of women politicians versus men politicians by media has been significantly unequal. As Ross (2003:1) illustrates, media 'trivialize their [women's] political contributions, undermine their political authority and, more generally, render them invisible'. The evidence of women's invisibility by the media is shown in a study comparing media coverage of Northern Irish candidates for the 1997 British General Election where women political candidates were significantly under-reported across 22 newspapers (Whittaker, 1999 cited in Ross, 2002). Also, if women politicians are allocated broadcasting time, female speeches are not only shortened in election campaigns (Zukowski, 2011; Siemienska, 2005; Marszalek-Kawa, 2010; Ross and Comrie, 2012) but rarely exceed 15 seconds (Norris and Lovenduski, 1995). However, I would argue that this phenomenon could be due to the political parties' failure to request significant time for women's debates.

Another argument raised by scholars related to media involvement in the coverage of women parliamentarians is that women politician images are very often based on gender stereotypes (Walsh, 2001; Kroom and Ekstrom, 2008). Sturken and Cartwright's (2001: 106) suggestion would be a good point of departure for this debate. Their interpretation of human images shows that:

'Images . . . provide a complex field in which power relations are exercised and looks are exchanged. As both spectators and subjects of images, we engage in and are subject to complex practices of looking and being looked at'.

For instance, images of the Northern Ireland Women's Coalition during the signing of the Northern Ireland peace settlement (4 April 1998), show women politicians crying and hugging each other. This representation of women's weakness and emotionality differed from the representation of men, who were characterized as strong, rational and strategic (Walsh, 2001). A case represented by Swedish politician: Gudrun Schymana ${ }^{1}$ justifies the above argument. She argued that media highlighted her femininity by:

1. Highlighting physical aspects of her femininity that go in line with the conventional gender stereotype.

2. Inviting the reader into her mental and emotional world.

3. Defining her "crime" as going against typical feminine behavior and traits

4. Relating her public persona to the feminine story-telling character of a princess (Kroon and Ekstrom, 2008:895)

\footnotetext{
${ }^{1}$ Gudrun Schyman: former leader of the Swedish Left Wing Party
} 
Additionally, in many instances, if women candidates are mentioned by the press it is only by association with their husband wealth or in a reference to their families (Ross, 2002). Also Szczepanska ${ }^{1}$ (cited in Marszalek-Kawa, 2010:183-184) often make comments such as 'women don't know about politics' or 'women's political crusade'. Danuta Waniek, Chairperson of Polish National TV and Radio Council, argues that women are always represented as 'unthinkable idiots' who are only capable of buying a soap powder (Biuro Studiowi Ekspertyz Kancelarii Sejmu, 2003:56). Similarly, a Polish TV commentator Anna Brzozowska exposes some comments by Polish TV presenter Andrzej Kwiatkowski during the political program called Prime Time whose standard statement was: 'such stupid women, but what clever things they are saying' (Biuro Studiowi Ekspertyz Kancelarii Sejmu, 2003: 77).

The above descriptions of females in politics affect their reputations as political leaders. One of the examples for this ontology is British MP Margaret Beckett (Labour Party), who has been constantly scrutinized by the media. For instance, during her election campaign in 1994 she was described as 'postmenopausal', 'too emotional', 'too female' and the one who had 'stolen another woman's husband'(Ross, 2002:1). Also a garish model would be an article in the Guardian where British journalist Simon Hattenstone described the former UK Shadow Home Secretary, Ann Widdecombe, as 'out of this world':

'Her head is tiny, trapped inside the jet-black basin cut, her legs nonexistent and she walks on a giant bosom. Her face is somehow not human. Not inhuman, just not human. She looks as if she could have been created by Stephen Spielberg as a companion for ET... I'm beginning to think Ann Widdecombe is from Planet Pod'

(Walsh, 2001: 46).

A further case of media misrepresentation was the coverage of policies formed by female politicians regarding the timetable in the Scottish Parliament. The family-friendly changes included the change of parliament sittings to normal working hours rather than evenings and parliamentary recesses to be harmonized with school holidays. These changes, however, have been presented by the media as women MPs' holiday extensions, completely suppressing the fact that most of the time has been used for constituency work (Walsh, 2001). Another distinctiveness dominating the media's image of women politicians is their sexual representation (Ross, 2002; Marszalek-Kawa, 2010). For example Cheryl Kernot (former Australian MP) and Pauline Hanson (Australian Labour MP) have been portrayal in the media using cartoon images of them in erotic situations with their male colleagues (Ross, 2002). Sexism within the male governed political sphere has been a debate by scholars for many years (Lovenduski and Karam, 2002; Fushara, 2009) as the media always pay too much attention to women's appearances (Devitt, 2002; Fushara, 2009; Abdela, 2010). For instance, Glenda Jackson (British Labour MP) complained

\footnotetext{
${ }^{1}$ Sonia Szczepanska, author of the article "Women: political animal"
} 
that a "woman's appearance, her age, her style of dress is always commented on" which sadly does not happen to male politicians (Ross, 2002:90). Besides, according to Graff (cited in Marszalek-Kawa, 2010), an attractive woman politician is unlucky as her image does not fit with the function she is carrying out. Dawn Primarolo's (British Labour MP) illustrates:

'Women are never the right age. We're too young, we're too old. We're too thin, we're too fat. We wear too much make-up, we don't wear enough. We're too flashy in our dress, we don't take enough care. There isn't a thing we can do that's right' (Ross, 2003:103).

Controversially, according to some researchers, on many occasions journalists do not favor men politicians (Devitt, 2002; Kroon and Ekstrom, 2008). For example, in Sweden a male politician who was interviewed by a researcher stated: I would like to emphasize that also a male politician is subject to an enormous amount of reviews about his appearance" (Kroon and Ekstrom, 2008:907). However, the examples of media portraying men politicians in this way are very uncommon and the main argument by politicians is that whereas men may experience 'silly or serious coverage', for women it 'is often either or' (Spence, 2012).

\section{Conclusions}

In this paper I have aimed to explain some reasons for gender imbalance in parliaments across new and established democracies in some countries belonging to OECD. I paid special attention to explore various difficulties that women are facing on their way to the political elite such as male domination of the parliamentary environment and media miss-representation of women politicians.

Male domination of the political arena is also presented in this paper as an explanation of the critical mass impact on the parliamentary environment. In addition women's MPs' impact on women's issues when in the office is highlighted in here. The literature enhances our understanding of women's role in the political process. The literature identifies how feminization and the promotion of women's interests influence the wider political environment (Lovenduski at el., 2005) with reference to concern that women MPs might represent mainly women's issues (Childs and Webb, 2012). Also, on many occasions women do not come forward either due to fear that they will not be able to compete against men or they should not take any interest in politics (Vallance, 1979; Karam and Lovenduski, 2005; Pankow and Post, 2010). Some research studies suggest that, if more women would put themselves forward politically, they not only would be recognized as potential politicians but also they would be nominated (Norris and Lovenduski, 1995). However change in the earlier mentioned cultural attitudes is needed to encourage more women to 
come forward (Ruedin, 2010). Also, the literature review identifies male involvement in women's political advancement. They fear feminization of politics and resent changes inside the male dominated house, built over many years a significant barrier to women's participation in parliament. However, Abdela (2010) indicates, that when equal partnership between both genders is established, men's domination is exchanged for positive relationships with women. In contrast, other scholars suggest that true equality between the sexes can only be achieved if both women and men pull together to break the age-old belief that women and men have different roles to play (Ballington, 2008: 5).

Also, the literature suggests that the media impact on women politicians by misrepresenting them they become political figures. Regrettably, the literature review evidence suggests that women politicians are not only highly underrepresented by media, but their image are been distorted, presenting them as gender stereotypes or/and sexual objects. The systematic tendencies to those discourses on female politicians by journalists and reporters lead to the conclusion that the media highly contribute to women's difficulties in their political careers. Also media bias against female politicians plays a big role in influencing public opinion about women's abilities and capabilities as politicians. These misrepresented descriptions of females in politics often damage their reputations as leaders and in many instances create an impediment to their future political careers. Therefore, guidance for women politicians in terms of development in public speaking through various forms of training such as education in voice projection, helping women to learn how to handle media so they become more sympathetic to women politicians, and how to become more visible are some of many strategies recommended by scholars (Lovenduski and Karam, 2002). Still this approach would have to acknowledge the importance of discourse between men and women about the prominence of parity in legislative bodies.

\section{References}

Abdela, L., (2010). "From palm tree to parliament: Training women for political leadership and public life". Gender \& Development. 8(3): 16-23

Ballington, J., (2008). Equality in Politics: A survey of Women and Men in Parliaments. Reports and Documents n 54. Geneva: IPU

Ballington, J., (2009), Equality in Politics A Survey of Women and Men in Parliaments An Overview of Key Findings. [Online] Available from: http:// www.ipu.org/PDF/publications/equality08-overview-e.pdf [Accessed: April 14, 2012].

Ballington, J., Karam, A., (2005). Women in Parliament: Beyond Numbers. A Revised Edition. Stockholm: Publications Office International IDEA

BBC News, (1998)., "UK Politics: Talking Politics The 'Mother of Parliaments"" [Online] Available at: http://news.bbc.co.uk/1/hi/uk_politics/96021.stm [Accessed: 02 December 2012]

BIS, 2011, Women on Board. [Online] Available at: http://www.bis.gov.uk/ assets/biscore/business-law/docs/w/11-745-women-on-boards.pdf [Accessed: 01 January 2012] 
Biuro Studiow I Ekspertyz Kancelarii Sejmu, (2003). Kobiety w gremiach decyzyjnych. Konferencje i Seminaria 8(52)03, Warszawa: Kancelaria Sejmu

Childs, S, (2004). New Labour's Women MP's: Women Representing Women New York: Routledge

Childs, S., Lovenduski, J., Campbell, R. (2005). Women at the top 2005, changing numbers, changing politics? London: Hansard Society

Childs, S., Krook, M.L., (2008). "Critical Mass Theory and Women's Political Representation". Political Studies. 56(3): 725-736

Childs, S., Webb, P., (2012). Sex, Gender and the Conservative Party. From Iron Lady to Kitten Heels. Basingstoke, New York: Palgrave Macmillan

Devitt, J. (2002). "Framing gender on the campaign trail: female gubernatorial candidates and the press". Journalism and Mass Communication Quarterly. 79(2): 445-463

Dahlerup, D., Freidenvall, L., (2008). Electoral Gender Quota Systems and their Implementation in Europe. [Online] Available from: http://www.europeanpwn. net/files/euquotaonderzoek.pdf [Accessed: April 14, 2012]

Du Vall, M., (2009).Wspolczesne Polki-trudnosc w wyborze rol in Fratczak, A., (2009). Kobiety wobec polityki- kobiety w polityce. Historia, realia, persepctywy. Krakow: Krakowska Akademia im. Andrzeja Frycza Modrzewskiego

Falk, E., (2008). Women for Presidency. Urbana and Chicago: University of Illinois Press

Fuszara, M., (2009). Kobiety $w$ polityce dwudziestolecia (1989-2009) in Raport congress Kobiet Polskich 2009. Kobiety dla Polski. Polska dla Kobiet. 20 lat transformacji 1989-2009.

Haffert, K., O’Connell, S., Ruthrauff, H., Powley, A., (2010). Democracy and the Challenge of Change A Guide to Increasing Women's Political Participation. [Online] Available from: http://www.ndi.org/files/Democracy_and_the_ Challenge_of_Change.pdf [Accessed: April 14, 2012].

Harman, H., Mattinson, D., (2000). Winning for Women. Fabian Society No. 596. London: The College Hill Press Limited.

Inglehart, R., Norris, P., (2003). Rising Tide. Gender Equality and Cultural Change Around the World. Cambridge: The Press Syndicate of the University of Cambridge

IPU (Inter-Parliamentary Union),(1997). Results 98 Conference and related meetings of the Inter-Parliamentary Union. Cairo(Egypt), 9-16 September 1997

IPU (Inter-Parliamentary Union),(1999). Participation of Women in Political Life. New York: IPU [Online] Available at: http://www.ipu.org/PDF/publications/ womenplus5_en.pdf [Accessed: 10 July 2012]

IPU (Inter-Parliamenatry Union), (2006a). Women in Politics: 60 years in retrospect. [Online] Available at: http://www.ipu.org/PDF/publications/wmninfokit06_ en.pdf [Accessed: 25 October 2012]

IPU (Inter-Parliamenatry Union), (2006b). Women in Parliament in 2006. The Year in Perspective. [Online] Available at: http://www.ipu.org/pdf/publications/wmn06e.pdf [Accessed: 25 October 2012]

IPU (Iner-Parlaimenatry Union), (2011). Women in Parliament in 2011. The Year in Perspective. [Online] Available at: http://www.ipu.org/pdf/publications/wmn persp11-e.pdf [Accessed: 20 July 2012]

IPU (Inter-parliamentary Union), (2012). Women in National Parliaments. [Online] Available from: http://www.ipu.org/wmn-e/world.htm [Accessed: 05 May 2013]

ipu.org/wmn-e/world.htm on 25 June 2012. 
Kampichler,M., Machovcova, K., (2008). "Gender Mainstreeming in the Czech Republic: a critical Perspective" in Grzybek, A., and Rochon, A., (eds). Gender Mainstreaming. Hope to Use Its Potential Effectively? Warsaw: Heinrich Boll Foundation Regional Office

King, O., (2005), "All-women shortlist a must, says report". The Guardian. Tuesday 15 November 2005 [Online] Available at: http://www.guardian.co.uk/politics/ 2005/nov/15/women.gender?INTCMP=ILCNETTXT3487 [Accessed: 05 May 2012]

Kittilson, M. C., (2006). Challenging Parties, Changing Parliaments. Women and Elected Office in Contemporary Western Europe. Ohio: The Ohio State University Press

Krolokke, Ch., Scott Sorensen, A., (2006). Gender Communication Theories and Analyses. London: Sage Publications

Krook, L., (2010). "Women's Representation in Parliament: A Qualitative Comparative Analysis". Political Studies. 58: 886-908

Kroom, L., Ekstrom, M., (2008). "The Complex Visual Gendering Of Political Women In The Press". Journalism studies. 9(6): 891-910

Lovenduski, J., (2001). "Women and Politics: Minority Representation or Critical Mass?" Parliamentary Affairs. 54(4): 743-758

Lovenduski, J., Karam, A., (2002). Women in Parliament: Making a Difference. International IDEA Women in Parliament. Stockholm [Online] Available at: http://www.idea.int [Accessed: 02 May 2012]

Marszalek-Kawa, J., (2010). Kobiety w Polityce. Torun: Wydawnictwo Adam Marszalek

Mediocre, D., (2011). All Women Shortlists: A Route To equality? [Online] Dreaming Genius [Online] Available from : http://www.dreaminggenius.com/2011/06/allwomen-shortlists-route-to-equality.html [Accessed: 01 June 2012]

Nelson, B.J., Chowdhury, N., (1994). Women and Politics Worldwide. New Haven and London: Yale University Press

Norris, P., (1996), “Women Politicians: Transforming Westminster?". Parliamentary

Affairs, 49(1): 89-102

Pankow, I., Post, B., (2010). Kobiety u Wladzy? Spojrzenie z Sejmu. Warszawa: Instytut Studiow Politycznych Polskiej Akademii Nauk

Pawlowski, L., Kierulf Dubrow, J., (2011). "Worlds Apart? Political theorists, Parliamentarians and the Meaning of Unequal Representation". Polish Sociological Review. 3(175): 301-314

Platek, M., (2004). "Hostages of Destiny: Gender Issues in Today's Poland". Feminist Review. 76(1): 5-25

Ross, K., (2002). Women, Politics, Media. Uneasy Relations in Comparative Perspectives. New Jersey: Hampton Press

Ross, K., (2003). "Women Politicians and Millstream Media: A Game of Two sides". Centre for Advancement of Women in Politics, School of Politics, Queen's University Belfast

Ross, K., Comrie, M., (2012). "The rules of the (leadership) game: Gender, politics and news". Journalism. 13(8): 969-984

Ruedin, D., (2010). The Representation of Women in National Parliaments: A Crossnational Comparison. Oxford University Press. European Sociological Review Advance Access published September 24, 2010.

Sawer, M., (2010) "Women and Elections" in LeDuc, 1., Niemi, R.G., Norris, P., (2010). Comparing Democracies 3. Elections and Voting in the 21st Century. London: Sage Publications Ltd 
Siemienska, R., (1997). Plec a Wybory. Od Wyborow Parlamentarnych do Wyborow Prezydenckich. Warszawa: Instytut Studiow Spolecznych

Spence, L., (2012). Debate: Media treatment of female politicians, which side is to blame? Current affairs blog [Online] Available form: http://blog.lewispr.com /2012/02/debate-media-treatment-of-female-politicians-which-side-is-to-blame. html [Accessed: 30 MAy 2013]

Squires, J., (2007). The New Politics of Gender Equality. Basingstoke: Palgrave Macmillan

Sroda, M., (2009). Kobiety i wladza. Warszawa: Wydawnictwo W.A.B.

Stevens, A., (2007). Women Power and Politics. Basingstoke: Palgrave Macmillan

Stockemer, D., (2007). "Why are there differences in the political representation of women in the 27 countries of the European Union?" Perspectives on European Politics and Society. 8(4): 476-493

Sturken, M., Cartwirght, L., (2001). Practices of Looking: an introduction to visual culture. Oxford: Oxford University Press

Tremblay, M., (2008).Women and Legislative Representation: Electoral Systems, Political Parties, and Sex Quotas. New York: Palgrave Macmillan

Unicef, (2007). The State of the World's Children 2007. Women and Children. The Double Dividend of Gender Equality [Online] Available at: http://www. unicef.org/sowc07/docs/sowc07.pdf [Accessed: 20 June 2012]

United Nations Statistics Division, (2012). "Statistics and indicators on women and men". [Online] Available at: http://unstats.un.org/unsd/demographic/products /indwm/default.htm [Accesed: 07 April 2012]

Vallance, E., (1979). Women in The House. A Study of Women Members of Parliament. London: The Athlone Press.

Walsh, C., (2001). Gender and Discourse. Language and power in politics, the church and organisations. Edinburgh and London: Pearson Education Ltd

Walby, S., (2004). "The European Union and gender Equality: Emergent Varieties of Gender Regime". Social Politics. 11(1): 4-29

Wangnerud, L., (2009). "Women in Parliaments: Descriptive and substantive Representation". Annual Review of Political Science. 12(1): 51-69

Wawrowski, L., (2007). Polityka Rownych szans. Instytucjonalne mechanizmy zwiekszania partycypacji kobiet $\mathrm{w}$ structurach politycznych na oprzykladzie panstw Europejskich. Torun: Wydawnictwo Adam Marszalek

Zukowski, A., (2011). Partycypacja Wyborcza Kobiet- Wyzwania i Dylematy. Torun: Centrum Studiow Wyborczych 